\title{
Epistemology of Arabic Language Learning Technology Development
}

\author{
Ahmad Nurcholis ${ }^{1 *}$, Nuryani ${ }^{2}$, Heri Efendi ${ }^{3}$, Syaikhu Ihsan Hidayatullah ${ }^{4}$ \\ ${ }^{1}$ Arabic Education Study Program Institut Agama Islam Negeri Tulungagung, Indonesia \\ ${ }^{2}$ Arabic Education Study Program Institut Agama Islam Negeri Tulungagung, Indonesia \\ ${ }^{3}$ Arabic Education Study Program Institut Agama Islam Negeri Tulungagung, Indonesia \\ ${ }^{4}$ Arabic Education Study Program Institut Agama Islam Negeri Tulungagung, Indonesia
}

\section{Article History:}

Received : October 01, 2020

Revised : November 11, 2020

Accepted : December 20, 2020

Published : June 01, 2021

Keywords:

Arabic; Digital; ICT; Model

*Correspondence Address: cholisahmad87@gmail.com

\begin{abstract}
Students' lack of Arabic language skills might be caused by the models and strategies used by teachers, the students' excitement in learning and their character. This study aimed to research on the epistemology of Arabic learning based on ICT. It was designed to find the Arabic learning model based on ICT. It assumed that integrating various fields of study with ICT, including Arabic language learning, is essential to be developed in this digital era. However, there are obstacles experienced by several schools, especially the teachers, they do not have a specific format for using ICT to integrate both scientific subjects. Descriptive qualitative research was used in this research. The data collection was done through observation, interviewing the teachers and one hundred X grade students, and documentation. The data were analyzed by using the Miles and Huberman technique. The results showed that the design of the ICT-based in Arabic learning model development is "al-hasub al-ittishali", this is an innovative Arabic learning model based on ICT. In this model, the materials and other learning tools are designed in a computer program. As stated by E. L. Criswell, computers provide opportunities for students to participate and respond to the student's activities actively. This model contributes in making the teaching and learning process more effective. With this model, the teacher is expectedly able to become a learning motivator and a mediator to explain some materials to the students. Besides, the use of ICT is a must considering the digital era.
\end{abstract}

\section{Introduction}

Students' lack of Arabic language skills can be caused by the models and strategies of teaching, students' attitude in learning and character ${ }^{1}$. Madrasah Aliyah (Islamic High School) students have been familiar with computers. Their familiarity with various ICT demands teachers' creativity to carry out the teaching and learning process according to their needs and passion. The learning model develops continuously in line

${ }^{1}$ Bruce Allen Knight and Susan A. Galletly, 'Bridging the Gap Between Reading Theory and Innovating Teacher Practice', International Journal of Innovation, Creativity, (2020): 11. 
with the development of language, education, and times ${ }^{2}$. Besides, many results of research in the field of language teaching also contribute to the improvement of new approaches and methods ${ }^{3}$. Most of these findings talk about English language teaching, as the most popular language in the world nowadays ${ }^{4}$.

Many researches have proven that the learning model supported by the use of instructional media showed a very significant influence on the students' ability to understand the material compared to the conventional instruction system ${ }^{5}$. Lecturing technique just helps learners to understand the material by $5 \%$. If the learning model develops with reading, the presentation will increase to $10 \%$, respectively audiovisual, demonstration, discussion, and practice will increase from $20 \%$ to $80 \%{ }^{6}$. Schramm argued that learning material is strongly influenced by the content and instructional model, and the kind of technology used ${ }^{7}$. On the other hand, Clark said that the use of technology (multimedia or computers) in learning can help the material preparation efficiently and effectively ${ }^{8}$. The use of computers for learning has been applied since the $60 \mathrm{~s}^{9}$, but computer is only a tutor which presents exercises but cannot provide feedback and give them rewards and punishments to help students be more motivated in learning ${ }^{10}$.

Fundamentally, ICT-based learning, then it is known as computer-based learning or Computer-Based Instruction (CBI) is a learning process with computers to deliver learning material by providing opportunities for students to participate and respond to the student's activities actively ${ }^{11}$. Made Wane also stated that ICT-based learning which is

\footnotetext{
${ }^{2}$ K. Joyce and N., 'Cartwight, "Bridging the Gap between Research and Practice: Predicting What Will Work Locally”, American Educational Research Journal, 57.3, (2020): 1045-1082.

${ }^{3}$ S. M. Anwaruddin, "Teachers" Engagement with Educational Research: Toward a Conceptual Framework for Locally-Based Interpretive', Interpretive Communities', Education Policy Analysis Archives, 23.40, (2015): 1-25.

${ }^{4}$ C. M. Connor \& F. J. Morrison, “'Individualizing Student Instruction in Reading: Implications for Policy and Practice",' Policy Insights from the Behavioral and Brain Sciences, 3.1, (2016): 54-61.

5 P. Hubbard, 'Learner Training for Effective Use of CALL, (State College PA: Center for Advance', Language Proficiency and Education and Research,(2006): 98.

${ }^{6}$ Yusring Sanusi Baso, Program Multimedia Bahasa Arab, (Padang: Prosiding PINBA IMLA, 2013), 221.

${ }^{7}$ Wilbur Schramm, Asas-asas Komunikasi Antar Manusia, Trans. Agus Setiadi, (Jakarta: LP3ES, 1977), 86.

${ }^{8}$ Richard E. Clark, "Reconsidering Research on Learning from Media",' Journal JSTOR, 53.4, (1983): 445-459.

9 Maysa' Abu Syanab, “Tiknulujia Ta'Allum AlLughah Al-“Arabiyah”,' Journal Al-Adab Wa AlTarbiyah, 2.32, (2007): 66.

${ }^{10}$ K. Glasswell, P. Singh \& S. McNaughton, "“Partners in Design: Co-Inquiry for Quality Teaching in Disadvantaged Schools", Australian', Journal of Language \& Literacy, 39.1, (2016): 20-29.

${ }^{11}$ E. L. Criswell, 'The Design of Computer Based Instruction', (New York: Macmillan Publishing Company, 1998), 1.
} 
presented through computers makes teaching and learning activities more interesting and challenging $^{12}$. A study conducted at one of state Islamic university showed that most lecturers $(90 \%)$ have used information technology-based learning media in Arabic learning ${ }^{13}$. A teacher's mastery in a certain language does not guarantee that he/she is skilled in teaching the language ${ }^{14}$. An Arabic teacher should have at least three skills such as 1) Arabic Proficiency, 2) Knowledge of Arabic language and culture, 3) Arabic teaching skills ${ }^{15}$. The use of ICT is inseparable from problems ${ }^{16}$, it is necessary to solve the obstacles in the application of ICT-based in Arabic learning. Furthermore, teachers are not into some innovative applications for learning mode ${ }^{17}$, Mahyudin Ritonga, Alwis Nazir, and Sri Wahyuni ${ }^{18}$ in their research on "ICT-based Arabic language learning in Padang" found that they utilize learning tools that have been designed in computer programs.

Meanwhile, Eka Utari Handayani ${ }^{19}$ in her research on "Arabic Language Curriculum Development Design using Video Media: Digital Technology Approach emphasizes that the use of Technology and Digital" in the form of video is a solution in solving academic problems related to limited time allocation in learning. Students can access online and offline anywhere and anytime. However, with a note that technology and digital are only a medium to help the learning process, in every learning process, teacher's guidance is needed. Rahmat Iswanto ${ }^{20}$ in his research on "Arabic Learning with the Utilization of Technology" found that technology has an important role in the harmony and sustainability of Arabic learning from elementary to high level. Rifqi Aulia

12 Wena Made, 'Strategi Pembelajaran Inovatif Kontemporer: Suatu Tinjauan Konseptual Operasional', (Jakarta: PT. Bumi Aksara, 2009), 203.

${ }^{13}$ Abdul Muntaqim, "The Use of Information Technology-Based Arabic Learning Media in the Arabic Language Center (PKPBA)', Universitas Islam Negeri Maulana Malik Ibrahim Malang', Tarling, 3.1 (2020): 41-58.

${ }^{14}$ B. A. Knight \& S. Galletly, ' Effective Literacy Instruction for All Students: A Time for Change,' International Journal of Innovation, Creativity and Change, 3.1, (2017): 65-86.

${ }^{15}$ Abdul 'Aziz Ibrahim, Al-'Ushaili, Asâsiyat Ta'Lîm Al-Lughah Al-'Arabiyah Li an-Nâthiqîn Bi Lughât Ukhra, (Riyadh: Jami'ah al-Imam Muhammad bin Su'ud al-Islamiyah, 1423 H), 268.

${ }^{16}$ B. A. Knight, S. Galletly, J. Morris, \& P. Gargett, "'Reading Instruction Strategies to Reduce Cognitive Load",' Practical Literacy: The Early and Primary Years, 23.2, (2018): 8-10.

${ }^{17}$ Jacqueline Manuel and Don Carter, 'Current and Historical Perspectives on Australian Teenagers' Reading Practices and Preferences', Australian Journal of Language and Literacy, 38.2, (2015): 115-128.

18 Mahyudin Ritonga, Alwis Nazir, and Sri Wahyuni, 'Pembelajaran Bahasa Arab Berbasis Teknologi Informasi Dan Komunikasi Di Kota Padang', Arabiyat: Jurnal Pendidikan Bahasa Arab Dan Kebahasaaraban, 3.1, (2016): 1-12.

${ }^{19}$ Eka Utari Handayani, “Desain Pengembangan Kurikulum Bahasa Arab Dengan Mengggunakan Media Video', Pendekatan Teknologi Digital', Taqdir, 4.2, (2019): 30.

${ }^{20}$ Rahmat Iswanto, 'Pembelajaran Bahasa Arab Dengan Pemanfaatan Teknologi', Arabiyatuna: Jurnal Bahasa Arab, 1.2, (2017): 143. 
Rahma and Indah Kumalasari ${ }^{21}$ in their research on "Epistemological Reconstruction of Arabic Language Education in a Disruptive Era" argued that scientific epistemology and curriculum need to be addressed and oriented towards the formation of competitive skills in this era.

Learning media has demonstrated its superiority ${ }^{22}$ in helping educators ${ }^{23}$ or teachers in the process of conveying the message of learning more quickly and easily caught by the students ${ }^{24}$. The media play a role in enriching the learning experience of students ${ }^{25}$, increasing their attention to the lesson ${ }^{26}$, and minimizing the diversity in perception between teachers and students as well as to help resolve personal differences between students ${ }^{27}$. Moreover, social media can be used as a tool for language learning Arabic $^{28}$ which can also improve students' skills ${ }^{29}$, and help the students to interact with lecturers and classmates ${ }^{30}$. Considering to some previous studies that have been mentioned, al-hasub al-ittishalî promoted a new paradigm of using computer for learning media. It is a computer-based application as well as media and model that can be operated by both teacher and student, equipped with various features that make learning more interesting and effective. Based on some arguments above, this study aimed to describe, analyze, and epistemologically interpret the development of Arabic learning technology.

${ }^{21}$ Rifqi Aulia Rahman and Indah Kumalasari, “'Rekonstruksi Epistemologis Pendidikan Bahasa Arab Di Era Disruptif",' Armala, 1.1, (2020): 24-40.

${ }^{22}$ Siti Rohmah Soekarba, 'Buku Al-Arabiyyatu Bayna Yadaik (Analisis Pengajaran Bahasa Arab Dalam Perspektif Lintas Budaya)', IJAS: Indonesian Journal of Arabic Studies, 1.2, (2019): 64.

${ }^{23}$ Donny Handriawan, “"Mempertegas Kembali Arah Pembelajaran Bahasa Arab"”, Al-Mahara, 1.1, (2015): 55

${ }^{24}$ Muhbib Abdul Wahab, 'Peran Bahasa Arab Dalam Pengembangan Ilmu Dan Peradaban Islam', ARABIYAT: Jurnal Pendidikan Bahasa Arab Dan Kebahasaaraban, 1.1, (2014): 3.

25 Muhzin Nawawi, "Pengembangan Kurikulum Pendidikan Bahasa Arab (Kajian Epistemologis)"”, An-Nabighoh, 19.1, (2017): 90-91.

${ }^{26}$ Muhbib Abdul Wahab, 'Standarisasi Kurikulum Pendidikan Bahasa Arab Di Perguruan Tinggi Keagamaan Islam Negeri', Arabiyat : Jurnal Pendidikan Bahasa Arab Dan Kebahasaaraban, 33.1, (2016): 34-35.

${ }^{27}$ Rais Abdullah, “"Teaching Media in the Teaching of Arabic Language to Non-Native Arabic Speakers"', Dinamika Ilmu, 16.1, (2016): 93-106.

${ }^{28}$ Nurul Hanani, 'Prospek Pendidikan Bahasa Arab di Indonesia Pada Era Perkembangan Zaman', Didaktika Religia, 4.2, (2016): 23-38.

${ }^{29}$ Rahmap, “Neologisasi Dalam Bahasa Arab"', Alfazuna, 1.1, (2016): 51-53.

${ }^{30}$ Risna Rianti, "'Students" Perception toward Social Media Assisted Language Learning (SMALL) for Arabic Learning,' Izdihar. 2.2, (2019): 101-14. 


\section{Method}

Descriptive research with a qualitative approach was used in this research. While the phenomenon is the Arabic Learning Technology Development in Islamic senior high school level. This is mainly because it is important to have a proper understanding of what is going on in the teaching learning process using computer. It provides more indepth examination and understanding of the learners and their behaviors and experiences. Qualitative and descriptive research is well suited to the study of second language classroom teaching, in this case Arabic language. The primary data is collected directly from the data source in the kind of the result of interview and documentation. It is reliable, authentic, and objective with the purpose of addressing to answer the research problems.

The research place was MAN 2 Blitar. This place had been chosen because this school has a computer laboratory that is optimally used for teaching and learning process than any other school in this city. The research instrument was the researchers themselves, as the planners, executors of data collection, data interpreters, and finally the reporter of the research result. The data sources were informants, activities, documents relating to the phenomenon. The informants were the Arabic teachers and of $\mathrm{X}$ grader students, selected by purposive sampling. The objects of the observation were the students' daily routines at school when they are using computer in learning. Data collection technique was done by interview and questionnaire, and documentation ${ }^{31}$.

Researchers used Miles and Huberman's data analysis, It is used to make sure the data is valid and can be trusted or not. In this research, the researcher used triangulation to check the validity of the data. Triangulation is the process of strengthening the finding by cross-checking the information. According to Miles and Huberman, triangulation is supposed to support a finding by showing that independent measures of it agree with it, or at least, do not contradict it. The procedures in qualitative data analysis are carried out interactively and continuously until the data were saturated, such as data reduction, data display, and drawing conclusions and verification. Theoretical triangulation or triangulation of theory were used as the type which is appropriate to be applied in this research. In this case, the researcher used more than one theory framework in interpreting the data. The theory selected by the researcher is the theories proposed by Stephen C. Levinson, George Yule, Peter

31 Lexy J. Moleong, "Metodologi Penelitian Kualitatif Edisi Revisi". (Bandung: Remaja Rosdakarya, 2019), 57. 
Grundy, and Singo Imai. Researchers used inductive, deductive, and comparative methods to analyze the data. Then, the data were validated by conducting a validity test. Besides, researchers also used in-depth observation techniques and peer debriefing methods ${ }^{32}$.

\section{Result and Discussion}

\section{Needs Analysis of Technology-Based Arabic Learning Objectives}

To find out the learning objectives in Madrasah Aliyah or senior high school level, researchers conducted a study on several aspects, such as the curriculum and learning tools used, the difficulties experienced by students, and the obstacles experienced by teachers in Arabic learning. Based on the results of observations, documentation, and interviews at three schools in Blitar, namely MA Negeri Wlingi, MA Negeri Tlogo Kanigoro, and MA Negeri Kunir Wonodadi, it is known that the three educational institutions use two types of curriculum, KTSP and K13. The diversity of the curriculum used impacts the teaching and learning process in all aspects. Both types of curriculum begin with preparing learning tools such as annual programs, semester programs, monthly programs, weekly programs, and lesson plans. It is in line with Refly Anwar's statement that every teacher is required to prepare all learning tools. A similar statement was also expressed by Kamarul Zaman that before starting the learning activities all teachers required to collect learning tools and submit them to the vice principal/vice curriculum, it is an important thing to maintain the quality of the learning process.

The availability of these learning tools is also reinforced by Nindita's statement, who said that all Arabic teachers always explain the objectives before delivering the material. Based on the analysis of the lesson plans, it is known that many learning materials must be integrated with Information and Communication Technology (ICT), such as material related to letters pronunciation, conversation, and tadrîb li mahârat alistimâ'. Lesson Plan is a must, include learning media to support and help students understand the material. Besides, students who attend the MA level in Blitar are not only those who have a background of Arabic knowledge, such as Madrasah Ibtidaiyah (Islamic Elementary School) or Madrasah Tsanawiyah (Islamic Junior High School), many students in three educational institutions also have educational backgrounds from

${ }^{32}$ Matthew B. Miles dan A. Michael Huberman, Analisis Data Kualitatif, Buku Sumber Tentang Metode-Metode Baru, (Penerbit Universitas Indonesia: UI-Press, 2014), 89. 
general school. They do not master Arabic deeply but they can read Al-Quran. Moreover, TPQ certificate is also necessary for students who want to continue their education to the MA/SLTA level.

The use of the strategies, methods, or media must be based on the material characteristics, the students' conditions, and the obstacles that get in the way of the material delivery ${ }^{33}$. The heterogonous students at these educational institutions influence the learning process, especially religious subjects, including Arabic. Students who have initial knowledge of Arabic, they know the meaning of some vocabularies often used in everyday life. In contrast, students who do not have basic knowledge of Arabic, they seem to feel something strange when learning Arabic. Based on the results of observations to the students, it can be seen that some students have a great willingness to learn Arabic. It is proven by students' attention in listening to the teachers' explanation, they do the teacher's orders to answer questions, complete the school and home assignments well, and try to practice speaking Arabic with friends even though it is still far from grammatically correct. In contrast, some students do not pay attention to Arabic lessons well, it can be seen that many students were chattering away with their peers, being lazy in doing school and home assignments.

On the other hand, it can also be seen that students often face difficulties, such as the difficulties in expressing Arabic sentences, practicing Arabic phrases, and answering the exercises in the worksheet. Thus, the students need a learning model that they can understand, use, and practice. A learning model includes all the material in two semesters. Because they have difficulty expressing Arabic sentences, the model is intended to be equipped with audio that students can listen to and it might contain various pictures that reinforce the students' understanding. Based on the needs analysis, the researcher designed an Arabic learning model named alhâsûb al-ittishâlî. The term of Al-hâsûb al-ittishâlî is the thought of the research team. This model is made to lead to a computer system that can interact and make the students focus on listening, paying attention, re-expressing, responding, doing exercises, so, they will know for their level of ability based on the score. The value is calculated by the computer system.

\footnotetext{
${ }^{33}$ Umi Machmudah, Ahmad Nurcholis, Yusuf Hanafi, Moh. Khasairi, "'Epitome" Solution to Nahw Instruction: Strategies toward "I'rab Reading" Abilities for Students', International Journal of Innovation, Creativity, and Change, 13.8, (2020): 832-849.
} 
Al-hâsûb al-ittishâlî model is defined as "communicative computers". The point is material related to listening ability, speaking ability, and reading ability equipped with audio which helps students to know how to pronounce and how to read with intonation properly and correctly. Materials are supported by audio, if the command menu is clicked, the audio and animation about the intended vocabulary are played, such as if the user clicks on the word الهرسة, the audio that expresses the word will be played and it is provided with an animated picture of a school. It happens to all words/vocabularies. In this model, the material related to conversations is also supported by audiovisuals in the form of conversations between two people, conversations among three people, and even conversations among four people. The role of actors in the designed audio-visuals is also adjusted to their portion, profession, and position in the conversation. For example, expressions related to the activities of students are played by the students, expressions related to the teachers are played by the teacher, and so on. The content of the model which is supported by audiovisual provides opportunities for students to practice with their friends as supported in al-hâsûb al-ittishâlî model.

The evaluation and training aspects contained in al-hâsûb alittishâlî model are designed to make students work on several variations of exercises. Especially for objective exercises, they will be able to find out their level of ability objectively and flexibly. This is because the natures of the exercises provide time limits and corrections. If the time limit to exercise has run out, the user cannot fix their answers anymore, and the system will release the scores, if the correct level reaches $100 \%$ then the system will release a praise animation with word "ممتاز", and if the correct level reaches $75 \%$, the system will show an animation with word "جيد", but if the completeness level is below 75\%, a pity animation will appear with a sentence "عليك أن تتعلم أيضيا".

Considering to the results of expert team validation and the results of trials and students' assessments of the models, it can be said that this designed model can be developed to be used as a source and media for Arabic learning The experts' judgment and students' assessment show a positive result. This model can be a learning resource because the contents of Arabic learning material for $10^{\text {th }}$ grade have also been included in students' textbook and worksheets. With the use of al-hâsûb al-ittishâlî model, both teachers and students can switch from textbook to computer-based. This model can be 
used as a learning media because it contains several pictures and audio that can support the learning process. With al-hâsûb al-ittishâlî model, teacher will not be busy in making and preparing the learning media and method. They only act as students' motivators and facilitators.

\section{Al-Hâsûb Al-ittishâlî Model and Arabic Language Skill Achievement}

\section{Listening Skills}

The material contained in this model includes Arabic learning material taught to the $10^{\text {th }}$ grade of Madrasah Aliyah Negeri (State Islamic Senior High School). This is inseparable from the curriculum used in $10^{\text {th }}$ grade, the 2013 curriculum, which requires the integration of a scientific approach. These materials are related to the material in the first semester and second semester. The content of this teaching material includes the vocabulary of each topic of conversation, examples of conversations, reading material for students from each topic, sentence patterns, and a grid of questions that can be answered directly by students and they can find out the value of their abilities within the specified time limit.

To help students listening skills, the design of Al-hâsûb alittishâlî model contains: (a) Arabic conversations, the conversation can be slowed down and can be repeated. It allows them to listen to what the speaker says according to the purpose of the conversation. (b) Arabic is used as the instructional language of the learning process. In the al-hâsûb al-ittishâlî model, all instruction for each learning material uses Arabic. It leads teachers to motivate students to use Arabic. (c) This model introduces several examples of Arabic speakers according to the topic and type of speech. This is beneficial for students so that they can distinguish how to express Arabic according to the context and type of conversation and help students to understand the situation where the conversation takes place. (d) Al-hâsûb al-ittishâlî model also provides opportunities for students so that they can learn independently and listen to learning materials outside the classroom. Because the designed model can be used by students themselves inside and outside the classroom. (e) In Al-hâsûb al-ittishâlî model, there is an example of listening evaluation in the form of audio that can be suppressed by themselves and they can select underneath some of the words provided to be selected. This leads students to be able to find out whether their answers match what they hear or not. The explanation above indicates that Al-hâsûb al-ittishâlı̂ model provides opportunities for teachers to become students' motivators and facilitators. This model also helps students' to listen to Arabic 81 | Jurnal Al Bayan: Jurnal Jurusan Pendidikan Bahasa Arab, 13 (1): 73-89 (2021) 
properly and correctly. Listening is a fundamental skill and one of the obstacles that teachers face in teaching Arabic is listening skills.

\section{Communication Skills}

One of the language skills that must be achieved is speaking skills. Several basic concepts should be understood by teachers before teaching a second language to students which are explained as follows: a) speaking and listening are two reciprocal activities, b) speaking is the process of individual communication, c) speaking is a creative expression, d) speaking is behavior, e) speaking is influenced by the experience, f) speaking is a means of expanding the horizons, and g) speaking is a personal emanation. Speaking skills can also build character. The integration of character values with Arabic subjects can be in the form of self-development programs, building the values, and ethics systems in the schools ${ }^{34}$.

By the basic concept above, al-hâsûb alittishâlî learning model is designed to help students have the skills to communicate in Arabic properly and correctly as follows: وأعد The pronunciation of vocabulary and sentences are combined with the command اسمع (listen and repeat). The point is that learning activities require active students to listen to the recording and then repeat it. (b) In this model, several words are also made without audio. The students are instructed to look at those words and then pronounce them. It provides the students to be able to identify words. (c) Al-hâsûb al-ittishâlî model also presents several pictures without Arabic words and how to read them. The picture is directed to practice communication skills among students through what is around them by expressing it in Arabic. (d) To improve the communication skills among students, alhâsûb al-ittishâlî model also provides games card that can be played by students both individually and in groups. For example, cards contain the certain words with a pointer to find the original object, cards that talk about something by role-playing. (e) As in the case of listening, this model also helps students to be able to communicate in Arabic according to the context and type of conversation, distinguishing the use of high tones, low tones, sad and happy expressions, and so on. This is inseparable from the presence of several examples of the type and context of speech. From some features of al-hâsûb al-

\footnotetext{
34 Ahmad Nurcholis, Budi Harianto, Ely Nur Khanifah, Syaikhu Ihsan Hidayatullah “"Pengembangan Kurikulum Bahasa Arab Berbasis Karakter Di MIN 1 Tulungagung”,' Arabiyatuna, 3.2 (2019): 283-298. See more Ahmad Nurcholis, Syaikhu Ihsan Hidayatullah, Muhamad Asngad Rudisunhaji, 'Karakteristik Dan Fungsi Qira'Ah Dalam Era Literasi Digital', El-Tsaqafah, 18.2, (2019): 283-98.
} 
ittishâlî model description above, it can be understood that this model can help students to communicate in Arabic properly and correctly. In helping this communication skill, the evaluation is more directed at practicing expressing words and sentences.

\section{Reading Skill}

Al-hâsûb al-ittishâlî learning model can also help students have good reading skills in Arabic. However, what is meant here is not reading in determining the line and position of words in a sentence, but reading skills that may be achieved with this model is reading of information, which is reading to obtain information ${ }^{35}$. This is inseparable from the reading material which has been arranged in such a way as to the learning materials. The most important thing is how students can recognize the reading text, interpret and use the vocabulary contained in the reading, understand the information contained in the reading explicitly and implicitly, understand the conceptual meaning, understand the communicative value of a sentence, interpret the reading, differentiate ideas main and supporting ideas, and determine the form factors to be used as a summary ${ }^{36}$.

By the objectives mentioned above, al-hâsûb al-ittishâlî model in reading skills is made by: ${ }^{37}$ (a) Reading material is extracted from existing vocabulary and conversation material. (b) From the reading material, students are required to be able to interpret and use important vocabulary in it related to the main material. (c) They are also expected to be able to reveal the information contained in the reading material. (d) In training, students are expected to be able to summarize the word categories contained in the reading. For example, they are expected to be able to collect a few words related to school facilities, house wares, family members, people at school, and others. (e) Students are also expected to be able to describe the contents of the reading again. For this reason, in al-hâsûb alittishâlî model, one of the aspects evaluated is how students can express main ideas and the general meaning of the reading material provided.

Reading skills in the al-hâsûb al-ittishâlî model are skills that are directed to be able to read well, understand the meaning of words or sentences, express the ideas contained in the reading text. For this reason, reading material is inseparable from

\footnotetext{
${ }^{35}$ Fatwiah Noor, 'Kurikulum Pembelajaran Bahasa Arab Di Perguruan Tinggi', Arabiyatuna: Jurnal Bahasa Arab, 2.1, (2018): 19.

${ }^{36}$ Fatih Rizqi Wibowo, 'Problematika Pembelajaran Bahasa Arab Kurikulum 2013', Al Mahāra: Jurnal Pendidikan Bahasa Arab, 2.1, (2016): 63-64.
} 
existing materials on the achievement of listening skills and speaking skills. With the relationship between the material of listening skills, speaking skills, and reading skills, this helps students to be able to read qirâ'ah (reading materials) or texts properly and correctly $^{38}$.

\section{Writing Skill}

Writing skill is one of the abilities that must be mastered by every language learner. It is the skill with the highest level of its difficulty for students compared to the other three language skills. Moreover, the cultural difference in writing Latin alphabets with Arabic characters is one of its difficulties for students ${ }^{39}$. Arabic writing that starts from right to the left remains a scourge that makes it difficult for students to achieve writing skills. In this case, it becomes the challenge for teachers to realize the students to be able to write Arabic, because writing down ideas itself is not easy, moreover they have to rewrite the sentences ${ }^{40}$. To achieve writing skills as described above, al-hâs $\hat{u} b$ alittishâlı̂ model provides the direction of learning kitâbah (writing skill) as follows: ${ }^{41}$ (a) Look up the words. The point is that students are given a kind of exercise to find the right pair of words in a sentence, find the correct word connection for a sentence, find the correct word in writing, and several other types of word searches. (b) Make a crossword puzzle. In this model, the kitâbah learning material is also described which directs students to be able to answer crossword puzzles. This type is intended to train the intelligence and memory of students on the material that has been learnt. (c) Elaboration. The students are required to be able to elaborate a word into a sentence or elaborate a statement into a question, and otherwise. (d) Descriptions. In al-hâsûb al-ittishâli model, the exercise gets the students to describe something into a sentence. For example, this model provides a picture, the students are expected to describe about what, who, how, when, why and where related to the picture. (e) Freewriting. Al-Hâsûb al-ittishâlî also offers and provides training for students to be able to write independently. The computer is given several topics that can be chosen by students freely, and they are then expected

\footnotetext{
${ }^{37}$ Ubaid Ridlo, 'Bahasa Arab Dalam Pusaran Arus Globalisasi: Antara Pesimisme Dan Optimisme', Ihyaul Arabiyah, 1.2, (2015): 222-224.

${ }^{38}$ Muhammedi, 'Perubahan Kurikulum Di Indonesia: Studi Kritis Tentang Upaya Menemukan Kurikulum Pendidikan Islam Yang Ideal', Raudhah, 4.1, (2016): 61.

39 Imam Syafe'i, 'Model Kurikulum Pesantren Salafiyah Dalam Perspektif Multikultural', AlTadzkiyyah: Jurnal Pendidikan Islam, 8.2, (2017): 128.

${ }^{40}$ Adtma A. Hasan., "“Model Pembelajaran CTL Berbasis IT Untuk Menguasai Mufrodat Bahasa Arab"”, Al-Lisan, 5.2, (2019): 135.
} 
to be able to write freely about the topics provided based on their knowledge, experiences, and what they feel in their lives.

To achieve the writing skills ability as described above, Al-hâsûb al-ittishâlı̂ model provides opportunities for students to express their ideas or thoughts either structurally or not. In a structured manner, the writing material contains a "topic" of discussion and there are also some vocabulary (mufradât) related to the theme to be used by students in expressing their thoughts ${ }^{42}$. Meanwhile, the exercise for writing ideas freely means in this model is that students are only given a "topic". They are free to express the content of their thoughts with the vocabulary (mufradât) they have. This training model is intended to have the ability of describing an object in a series of sentences that can be understood by others ${ }^{43}$. From the description above, it can be seen that al-hâsûb al-ittishâlî model which can help teachers to integrate Arabic learning materials, media, and methods, and this model also helps them to more easily provide understanding about Arabic learning materials for students. ${ }^{44}$ Besides, this model can also encourage students' self-motivation to be more active in participating in Arabic learning. Al-hâsûb al-ittishâlî model provides opportunities for students to be able to learn Arabic easily and independently, it also contains various training models that students can do independently and they can find out the results of their work ${ }^{45}$.

\section{Conclusion}

The purpose of ICT-based in Arabic learning, especially with al-hâsûb al-ittishâlî model is to maintain the quality of the learning process. This model is designed for the $10^{\text {th }}$ grade in Madrasah Aliyah (Islamic Senior High School) level. The results of the validation from the experts and the test results show that the feasibility of the designed learning model is in a good category. This can be seen in terms of material, display quality, and organization. This model can be seen as Arabic learning material, because in

${ }^{41}$ Dina Indriana, “"Evaluasi Pembelajaran Dan Penelitian Autentik Dalam Pembelajaran Bahasa Arab", Al-Ittijah, 10.2, (2018): 46-51.

${ }^{42}$ A. Dzo'ul Milal, “"The Curricular and Extra Curricular System of TEFL: A Case Study at Pondok Modern Gontor Indonesia”, Indonesian Journal of English Teaching, 1.2, (2013): 15.

43 Abdurrahman Faridi, "Inovasi Pembelajaran Bahasa Inggris Berbasis ICT Dalam Rangka Meningkatkan Mutu Pendidikan', Jurnal Lembaran Ilmu Kependidikan, 38.1 (2009): 34.

${ }^{44}$ Mohammad Ahsanuddin, "Pemanfaatan Internet Dalam Pembelajaran Bahasa Arab", Al-Arabi, 3.1, (2005): 1-13.

${ }^{45}$ Zughrofiyatun Najah and Azzah Saniyyah Maulana, 'Mahârah Al-Kitâbah Learning Through Mind Mapping Strategies', Jurnal Al-Bayan: Jurnal Jurusan Pendidikan Bahasa Arab, 11.2, (2019): 340355.

85 | Jurnal Al Bayan: Jurnal Jurusan Pendidikan Bahasa Arab, 13 (1): 73-89 (2021) 
this model contains Arabic learning material for $10^{\text {th }}$ grade as a whole, starting from material related to vocabulary (mufradât), material about the conversation (hiwâr), reading (qirâ'ah), writing material (kitâbah), sentence patterns (tarâkîb) to evaluation material with its various variations. Al-hâsûb al-ittishâlî model can also be seen as an Arabic learning media because it can be used as a learning facility to help students understand Arabic easily. Besides, this model can also increase the motivation of students to be more active in Arabic learning, this model can be operated by students outside of class such as at home. The researchers have learned much from the involvement of this research partners in our research team, although many aspects of our approach worked well, we would do further action and something different in the future. In this digital era, the next researchers can talk more about the use of mobile phone for teaching and learning process.

\section{Acknowledgment}

The researchers would like to thank the principal of MAN Wlingi, MAN Tlogo Kanigoro, and MAN Kunir Wonodadi for the attention, knowledge, and high enthusiasm for our concept to produce research that does not come out from the real conditions in the field.

\section{References}

A. Dzo'ul Milal, 'The Curricular and Extra Curricular System of TEFL: A Case Study at Pondok Modern Gontor Indonesia', Indonesian Journal of English Teaching, 1.2, (2013): 15.

Abdul 'Aziz Ibrahim, Al-'Ushaili, Asâsiyat Ta'Lîm Al-Lughah Al-'Arabiyah Li anNâthiqîn Bi Lughât Ukhra, Riyadh: Jami'ah al-Imam Muhammad bin Su'ud alIslamiyah, $1423 \mathrm{H}$.

Abdul Muntaqim, "The Use of Information Technology-Based Arabic Learning Media in the Arabic Language Center (PKPBA)', Universitas Islam Negeri Maulana Malik Ibrahim Malang', Tarling, 3.1 (2020): 41-58.

Abdul Wahab, Muhbib, 'Standarisasi Kurikulum Pendidikan Bahasa Arab Di Perguruan Tinggi Keagamaan Islam Negeri', Arabiyat: Jurnal Pendidikan Bahasa Arab Dan Kebahasaaraban, 33.1 (2016): 34-35.

Abdurrahman Faridi, “Inovasi Pembelajaran Bahasa Inggris Berbasis ICT Dalam Rangka Meningkatkan Mutu Pendidikan', Jurnal Lembaran Ilmu Kependidikan, 38.1, (2009): 34 . 
Adtma A. Hasan., “"Model Pembelajaran CTL Berbasis IT Untuk Menguasai Mufrodat Bahasa Arab"”, Al-Lisan, 5.2, (2019): 135.

Ahmad Nurcholis, Budi Harianto, Ely Nur Khanifah, Syaikhu Ihsan, "Pengembangan Kurikulum Bahasa Arab Berbasis Karakter Di MIN 1 Tulungagung", Arabiyatuna, 3.2 (2019): 283-298.

Ahmad Nurcholis, Syaikhu Ihsan Hidayatullah, Muhamad Asngad Rudisunhaji, 'Karakteristik Dan Fungsi Qira'Ah Dalam Era Literasi Digital', El-Tsaqafah, 18.2, (2019): 131-146.

B. A. Knight, S. Galletly, J. Morris, \& P. Gargett, "'Reading Instruction Strategies to Reduce Cognitive Load", Practical Literacy: The Early and Primary Years, 23.2, (2018): 65-86.

B. A. Knight \& S. Galletly, "Effective Literacy Instruction for All Students: A Time for Change,' International Journal of Innovation, Creativity and Change, 3.1, (2107): 65-86.

Bruce Allen Knight and Susan A. Galletly, 'Bridging the Gap Between Reading Theory and Innovating Teacher Practice', International Journal of Innovation, Creativity, 13.8, (2020): 11 .

C. M. Connor \& F. J. Morrison, "Individualizing Student Instruction in Reading: Implications for Policy and Practice",' Policy Insights from the Behavioral and Brain Sciences, 3.1, (2016): 54-61.

Dina Indriana, "Evaluasi Pembelajaran Dan Penelitian Autentik Dalam Pembelajaran Bahasa Arab",' Al-Ittijah, 10.2, (2018): 46-51.

Donny Handriawan, "Mempertegas Kembali Arah Pembelajaran Bahasa Arab", AlMahara, 1.1, (2015): 55.

E. L. Criswell, 'The Design of Computer Based Instruction', New York: Macmillan Publishing Company, 1998.

Eka Utari Handayani, "Desain Pengembangan Kurikulum Bahasa Arab Dengan Mengggunakan Media Video', Pendekatan Teknologi Digital', Taqdir, 4.2, (2019): 30 .

Hanani, Nurul, 'Prospek Pendidikan Bahasa Arab Di Indonesia Pada Era Perkembangan Zaman', Didaktika Religia, 4.2, (2016): 27.

Huberman, Matthew B. Miles dan A. Michael, Analisis Data Kualitatif, Buku Sumber Tentang Metode-Metode Baru, Jakarta: UI-Press, 2014.

Iswanto, Rahmat, 'Pembelajaran Bahasa Arab Dengan Pemanfaatan Teknologi', Arabiyatuna: Jurnal Bahasa Arab, 1.2 (2017): 143.

K. Glasswell, P. Singh \& S. McNaughton, "Partners in Design: Co-Inquiry for Quality Teaching in Disadvantaged Schools", Australian', Journal of Language \& 87 | Jurnal Al Bayan: Jurnal Jurusan Pendidikan Bahasa Arab, 13 (1): 73-89 (2021) 
Literacy, 39.1, (2016): 20-29.

K. Joyce and N., "Cartwight, "Bridging the Gap between Research and Practice: Predicting What Will Work Locally", American Educational Research Journal, 57.3, (2020): 1045-1082.

Made, Wena, 'Strategi Pembelajaran Inovatif Kontemporer: Suatu Tinjauan Konseptual Operasional', Jakarta: PT. Bumi Aksara, 2009.

Manuel, Jacqueline, and Don Carter, 'Current and Historical Perspectives on Australian Teenagers' Reading Practices and Preferences', Australian Journal of Language and Literacy, 38.2, (2015): 115-128.

Maysa' Abu Syanab, “Tiknulujia Ta'Allum AlLughah Al-“Arabiyah”,' Journal Al-Adab Wa AlTarbiyah, 2.32, (2007): 66.

Mohammad Ahsanuddin, "Pemanfaatan Internet Dalam Pembelajaran Bahasa Arab", Al-Arabi, 3.1, (2005): 1-13.

Moleong, Lexy J.,"Metodologi Penelitian Kualitatif Edisi Revisi”. Bandung: Remaja Rosdakarya, 2019.

Muhammedi, 'Perubahan Kurikulum Di Indonesia: Studi Kritis Tentang Upaya Menemukan Kurikulum Pendidikan Islam Yang Ideal', Raudhah, 4.1, (2016): 61.

Muhzin Nawawi, 'Pengembangan Kurikulum Pendidikan Bahasa Arab (Kajian Epistemologis)', An-Nabighoh, 19.1 (2017): 90-91.

Najah, Zughrofiyatun, and Azzah Saniyyah Maulana, 'Mahârah Al-Kitâbah Learning Through Mind Mapping Strategies', Jurnal Al-Bayan: Jurnal Jurusan Pendidikan Bahasa Arab, 11.2, (2019): 340-355.

Noor, Fatwiah, 'Kurikulum Pembelajaran Bahasa Arab Di Perguruan Tinggi', Arabiyatuna: Jurnal Bahasa Arab, 2.1, (2018): 19.

P. Hubbard, "Learner Training for Effective Use of CALL". State College PA: Center for Advance', 2006.

Rahmap, “"Neologisasi Dalam Bahasa Arab”, Alfazuna, 1.1 (2016): 51-53.

Rais Abdullah, “Teaching Media in the Teaching of Arabic Language to Non-Native Arabic Speakers"', Dinamika Ilmu, 16.1, (2016): 93-106.

Richard E. Clark, “"Reconsidering Research on Learning from Media”,' Journal JSTOR, 53.4, (1983): 445-459.

Rifqi Aulia Rahman and Indah Kumalasari, “"Rekonstruksi Epistemologis Pendidikan Bahasa Arab Di Era Disruptif',' Armala, 1.1, (2020): 24-40.

Risna Rianti, "'Students" Perception toward Social Media Assisted Language Learning (SMALL) for Arabic Learning,' Izdihar. 2.2, (2019): 101-114. 
Ritonga, Mahyudin, Alwis Nazir, and Sri Wahyuni, 'Pembelajaran Bahasa Arab Berbasis Teknologi Informasi Dan Komunikasi Di Kota Padang', Arabiyat: Jurnal Pendidikan Bahasa Arab Dan Kebahasaaraban, 3.1 (2016): 1-12.

S. M. Anwaruddin, "Teachers" Engagement with Educational Research: Toward a Conceptual Framework for Locally-Based Interpretive', Interpretive Communities', Education Policy Analysis Archives, 23.40, (2015): 1-25.

Soekarba, Siti Rohmah, 'Buku Al-Arabiyyatu Bayna Yadaik (Analisis Pengajaran Bahasa Arab Dalam Perspektif Lintas Budaya)', IJAS: Indonesian Journal of Arabic Studies, 1.2, (2019): 64.

Syafe'i, Imam, 'Model Kurikulum Pesantren Salafiyah Dalam Perspektif Multikultural', Al-Tadzkiyyah: Jurnal Pendidikan Islam, 8.2, (2017): 128.

Ubaid Ridlo, "Bahasa Arab Dalam Pusaran Arus Globalisasi: Antara Pesimisme Dan Optimisme"', Ihyaul Arabiyah, 1.2, (2015): 222-224.

Umi Machmudah, Ahmad Nurcholis, Yusuf Hanafi, Moh. Khasairi, "'"Epitome" Solution to Nahw Instruction: Strategies toward "I'rab Reading" Abilities for Students', International Journal of Innovation, Creativity, and Change, 13.8, (2020): 832-849.

Wahab, Muhbib Abdul, 'Peran Bahasa Arab Dalam Pengembangan Ilmu Dan Peradaban Islam', ARABIYAT: Jurnal Pendidikan Bahasa Arab Dan Kebahasaaraban, vol.no, (2014): 3 .

Wibowo, Fatih Rizqi, 'Problematika Pembelajaran Bahasa Arab Kurikulum 2013', Al Mahāra: Jurnal Pendidikan Bahasa Arab, 2.1, (2016): 63-64

Yusring Sanusi Baso, Program Multimedia Bahasa Arab, Padang: Prosiding PINBA IMLA, 2013. 